MAŁGORZATA KOWALSKA

Instytut Informacji Naukowej i Bibliologii

Uniwersytet Mikołaja Kopernika w Toruniu

email: koma@umk.pl

\title{
ALTMETRIA JAKO PRZEDMIOT ZAINTERESOWANIA BIBLIOLOGII I INFORMATOLOGII*
}

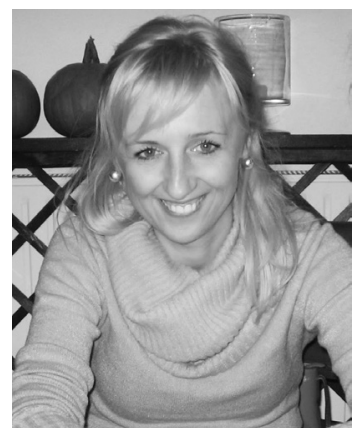

Absolwentka bibliotekoznawstwa i informacji naukowo-technicznej oraz filologii germańskiej na Uniwersytecie Mikołaja Kopernika w Toruniu, adiunkt w Zakładzie Informacji Naukowej Instytutu Informacji Naukowej i Bibliologii UMK. Jej zainteresowania naukowe koncentrują się wokół informatologii jako dyscypliny naukowej, infobrokerstwa, zasobów cyfrowych, wykorzystania crowdsourcingu w działalności instytucji sektora kultury. Autorka dwóch monografii (Crowdsourcing internetowypozytywny wymiar partycypacji społecznej. Konteksty - istota - uwarunkowania. Warszawa: Wydaw. SBP, 2015; Dygitalizacja zbiorów bibliotek polskich. Warszawa: Wydaw. SBP, 2007), współredaktor czterech wydawnictw zbiorowych, redaktor naukowy periodyku „Toruńskie Studia Bibliologiczne" oraz ponad 80 artykułów naukowych. Autorka kursów e-learningowych dla bibliotekarzy „BIBWEB”, , ,Login: Biblioteka”, ,Infobrokering”. Członek Międzynarodowego Towarzystwa Zarządzania Wiedzą - ISKO, Interdyscyplinarnego Zespołu Ministra Nauki i Szkolnictwa Wyższego ds. Upowszechniania Nauki oraz Sekretarz Komisji Bibliografii i Bibliotekoznawstwa Towarzystwa Naukowego w Toruniu.

SŁOWA KLUCZOWE: Altmetria. Bibliologia i informatologia. Metryki alternatywne. Ocena dorobku naukowego.

ABSTRAKT: Teza/cel artykułu - Niniejszy artykuł omawia istotę wskaźników altmetrycznych w ocenie dorobku naukowego oraz podejmuje próbę udzielenia odpowiedzi na pytanie, $\mathrm{w}$ jakim stopniu problematyka nowych rodzajów metryk stanowi przedmiot zainteresowa-

* Badania przeprowadzono w ramach grantu 2013/11/B/HS2/03048 Badanie struktury i dynamiki cyfrowych zasobów wiedzy za pomocą metod wizualizacji. 
nia badaczy z zakresu bibliologii i informatologii. Metody badań - Autorka przeprowadza analizę zawartości czasopism z zakresu biblio- i informatologii, w wyniku której wyłania najczęściej podejmowane obszary tematyczne odnoszące się do zagadnienia altmetrii. Wyniki i wnioski - Przeprowadzone badania dowodzą dużej popularności problematyki metryk alternatywnych $\mathrm{w}$ piśmiennictwie z zakresu biblio- i informatologii, zwłaszcza w ostatnich trzech latach. Autorka stoi na stanowisku, że zainteresowanie tematyką altmetrii będzie nadal rosło, a same altmetryki odegrają w przyszłości istotną rolę w ocenie publikacji naukowych.

\section{WPROWADZENIE}

System punktowania dorobku naukowego to od wielu lat czynnik determinujący ocenę działalności pojedynczego badacza. O ile dla reprezentantów nauk ścisłych, medycznych czy przyrodniczych, z uwagi na wysoki poziom umiędzynarodowienia badań naukowych, stanowi on element mobilizujący, choćby w zakresie pozyskiwania funduszy na badania, to wśród wielu przedstawicieli nauk społecznych i humanistycznych, spoglądających na niego przede wszystkim z lokalnej perspektywy, budzi sprzeciw i jest czynnikiem stresogennym. Z jednej strony w środowiskach tych podnosi się bowiem, że bazuje on na niemiarodajnych wskaźnikach bibliometrycznych (por. Osiński, 2012), z drugiej - że presja zamieszczania publikacji w międzynarodowych czasopismach o wysokich współczynnikach wpływu, odsuwa inne wymiary życia naukowego w cień. Tymczasem „wyjaśnienie dorobku naukowego musi brać pod uwagę osobiste (indywidualne) i strukturalne (środowiskowe) czynniki, a najlepiej również interakcje zachodzące między nimi” (Kwiek, 2015, s. 413, 277-280). W tej sytuacji nie dziwią coraz częściej słyszalne głosy wskazujące na konieczność uwzględniania w ocenie dorobku naukowego także alternatywnych mierników, pochodzących z elektronicznych kanałów komunikacji naukowej, takich jak blogi, serwisy społecznościowe, platformy dedykowane naukowcom, menedżery bibliografii, otwarte repozytoria, witryny umożliwiające dzielenie się prezentacjami multimedialnymi, zarządzanie zakładkami i rekomendujące artefakty naukowe. Ten nowy obszar oceny społecznego wpływu nauki określany jest mianem altmetrii, zaś wykorzystywane alternatywne względem tradycyjnych mierniki (alternative metrics) - wskaźnikami altmetrycznymi.

Termin altmetria po raz pierwszy pojawił się w opublikowanej online w 2010 r. pracy Altmetrics: a manifesto autorstwa Jasona Priema, Dario Taraborellego, Paula Grotha i Camerona Neylona. Mianem tym autorzy określili przejawy funkcjonowania badaczy w mediach elektronicznych i serwisach oferowanych przez Web 2.0, które - ich zdaniem - o wiele lepiej niż wskaźniki tradycyjne nadają się do mierzenia społecznego wpływu nauki. Jak dowodzili autorzy, nowe rodzaje metryk (tweety, polubienia, zakładki, wpisy na blogach, dane z menedżerów bibliografii), przyczyniają się do większej widoczności i szybszej popularyzacji dorobku naukowego. Stwarzają także lepszy dostęp do danych surowych, pozwalają na odnajdywanie 
wartościowych, niepublikowanych dotąd zasobów naukowych, pomagają w tworzeniu rekomendacji i wpływają na przyspieszenie procesu recenzowania (Priem et al., 2010).

Przegląd literatury dowodzi, że obecnie termin wskaźniki altmetryczne bywa różnie interpretowany (Rothe, Schmitz, 2016; Rychlik, 2012). Z jednej strony (ujęcie szersze) określa się nim zestaw mierników analizujących wpływ całych czasopism, czy też zbiorów monografii z danej dziedziny, jak i aktywność badaczy w wielodyscyplinarnych społecznościach internetowych (m.in. obecność w ogólnych portalach społecznościowych, sieciach dla naukowców, na naukowych blogach, serwisach zakładkowych; por. np. Hoffmann, Lutz, Meckel, 2016), z drugiej - dane generowane dla potrzeb pojedynczego artykułu, które mierzą jego oddziaływanie za pomocą tradycyjnych i społecznościowych mierników (article-level metrics, ALM; zob. np. Fenner, Linn, 2015). W niniejszym artykule dla potrzeb analizy piśmiennictwa fachowego przyjęto zintegrowane podejście do terminu wskaźniki alternatywne (altmetryki), co zaowocowało zgromadzeniem publikacji dotyczących zarówno oceny wpływu pojedynczych artykułów naukowych, jak i aktywności badaczy w mediach społecznościowych.

\section{MOCNE I SŁABE STRONY METRYK ALTERNATYWNYCH}

Ponieważ wskaźniki altmetryczne bazują na obecności badaczy w sieci, wywołują one - podobnie jak media społecznościowe - zarówno pozytywne reakcje, jak i liczne kontrowersje.

Zwolennicy altmetrii najczęściej podkreślają że w porównaniu z tradycyjnymi wskaźnikami bibliometrycznymi metryki alternatywne pozwalają badać wpływ dorobku naukowego w szerszym kontekście, tj. wśród rozmaitych kategorii użytkowników, niekoniecznie związanych ze środowiskiem naukowym (badania tradycyjnych cytowań w zasadzie poza ten krag nie wychodzą) (Adie, 2015). Ponadto stwarzają one szansę „monitorowania” różnych przejawów działalności naukowej - wpisów na blogach, rekomendacji, komentarzy i głosów w dyskusjach, upublicznionych danych surowych, materiałów niepublikowanych $\mathrm{w}$ formie tradycyjnej itp.(Bornmann, 2014). Do zalet często podnoszonych przez zwolenników nowych metryk należą także szybkość pozyskiwania przez naukowców informacji zwrotnej na temat swojego dorobku (możliwość śledzenia zainteresowania w czasie rzeczywistym) oraz dostępność danych altmetrycznych - w odróżnieniu od licencjonowanych baz bibliometrycznych - w różnego rodzaju serwisach (m.in. Twitter, Facebook, Google+, Google Scholar, BibSonomy, Figshare, CiteULike, Goodreads, LinkedIn, ResearchGate, Academia.eu, Slideshare, Wikipedia, Zotero, Mendeley) i za pomocą coraz liczniej powstających narzędzi je agregujących (takich jak np. Altmetric Explorer, PlumX, Impactstory, Altmetric It!, Lagotto, Publisso, CiteIn, Webometrics Analyst 2.0) (Robinson-Garcia et. al., 2014). 
Głównym zastrzeżeniem formułowanym wobec metryk alternatywnych jest z kolei brak ich standaryzacji, a więc określenia przez dostawców danych sposobów pozyskiwania i archiwizacji danych, weryfikacji ich jakości, częstotliwości aktualizowania oraz poziomów udostępniania użytkownikom, a co za tym idzie brak możliwości kontroli i porównywania oddziaływania wskaźników pochodzących z różnych źródeł (por. Gumpenberger, Glänzel, Gorraiz, 2016). O ile dla zwolenników altmetrii generowanie metryk w czasie rzeczywistym stanowi o ich potencjale, to dla przeciwników świadczy o niestabilności czy też tymczasowości nowego rodzaju wskaźników i w zasadzie dyskwalifikuje je jako rzetelne indykatory oceny wpływu danego badacza (obecnie mierzą przede wszystkim ilość wzmianek/wywołań w mediach, a nie ich jakość, por. Altmetrics for Researchers..., 2015). Ponadto w literaturze przedmiotu podkreśla się dużą podatność nowego rodzaju metryk na rozmaite manipulacje (np. nadinterpretacje danych, brak kontroli w ich tworzeniu, autowzmiankowania, udostępnianie własnych wpisów, cytowania na blogach własnych publikacji i rekomendowania ich w serwisach oceniających, tworzenie kręgów wzajemnych adoracji, inicjowanie sztucznych dyskusji czy dodawanie do kręgu znajomych osób posiadających wysokie wartości współczynnika naukowego wpływu w danym serwisie (por. Roemer, Borchardt, 2015). Ostatnim, bardzo istotnym zarzutem, stawianym altmetrykom jest intencjonalność. Cechę tę utożsamia się z jednej strony z preferencjami badaczy co do obecności w ściśle określonych serwisach dla naukowców (serwisy oferują różne formy zaangażowania użytkownika koncowego i mniej lub bardziej nadają się do wykorzystywania w określonych dziedzinach nauki, por. Mellero, 2015; Ortega, 2015), czy też dostarczaniem przez agregatory danych wyłącznie wybranych rodzajów metryk (Konkiel, 2013). Z drugiej strony zwraca się uwagę na fakt, że w elektronicznych kanałach komunikacji - źródłach generujących nowego rodzaju wskaźniki - nie uwzględnia się publikacji, które nie zostały opatrzone identyfikatorem obiektu cyfrowego, czy takich, które ukazały się przed laty wyłącznie w formie drukowanej, a dotąd nie zostały poddane procesowi digitalizacji (Ross, 2013).

Ponieważ nie sposób zaprzeczyć przywołanym zastrzeżeniom, trzeba zgodzić się z autorami Altmetrics: a manifesto, że wskaźniki altmetryczne nie powinny zastępować dotychczasowych metod oceny, zwłaszcza oceny eksperckiej, bo nie stanowią panaceum na wszystkie bolączki systemu punktowego. Mogą jednak ten system - pod pewnymi warunkami - uzupełniać.

\section{ZAINTERESOWANIE PROBLEMATYKĄ ALTERNATYWNYCH METRYK W ARTYKUŁACH Z ZAKRESU BIBLIO-I INFORMATOLOGII}

Zgodnie z zamierzeniami Priema i współpracowników, publikacja opisująca nową propozycję w zakresie całościowej oceny dorobku naukowego, odbiła się głośnym echem w środowisku naukowym i zaowo- 
cowała ożywioną dyskusją oraz znacznym przyrostem liczby publikacji na ten temat.

Potwierdzenie tej tezy przynoszą wyniki przeprowadzonej w marcu 2017 r. penetracji zasobów abstraktowo-bibliometrycznej bazy danych Web of Science Core Collection (dalej: WoS CC) ${ }^{1}$. Dowodzą one istnienia 1824 publikacji poświęconych różnym aspektom altmetrii. Wybór filtra „research area" uwidacznia, że najczęściej problematyka ta podejmowana jest w piśmiennictwie z zakresu informatyki (422 pozycje), inżynierii (310), biblioi informatologii (146), telekomunikacji (133) i ekonomiki przedsiębiorstw (83). W przypadku pozostałych dyscyplin naukowych zbiór wyświetlonych opisów bibliograficznych nie przekracza 80 pozycji.

Obecność na liście wyników wyszukiwania stosunkowo licznej grupy dokumentów reprezentujących biblio- i informatologię skłoniła autorkę do przeprowadzenia analiz udzielających odpowiedzi na pytanie, jakie zagadnienia szczegółowe dotyczące altmetrii porusza się w piśmiennictwie z tego zakresu. Dążenie do rzetelnego wykonania tego zadania pociągnęło za sobą konieczność sięgnięcia do zasobów dziedzinowej bazy danych Library, Information Science and Technology Abstracts (dalej: LISTA) - obejmującej piśmiennictwo z zakresu takich aspektów bibliotekoznawstwa i nauki o informacji, jak bibliotekarstwo, klasyfikacja, katalogowanie, bibliometria, wyszukiwanie informacji online i zarządzanie informacją. Zainicjowany w niej proces wyszukiwania ${ }^{2}$ pozwolił na uzyskanie zbioru 433 dokumentów: 235 artykułów z czasopism naukowych, 84 artykułów z czasopism popularnych (czasopisma drukowane i elektroniczne, newslettery, biuletyny, przeglądy itp.), 53 artykułów pochodzących z periodyków branżowych, 51 recenzji oraz 1 artykułu z gazety ${ }^{3}$. Ze względów merytorycznych ${ }^{4}$, do dalszych analiz zakwalifikowano 222 ar-

\footnotetext{
${ }^{1}$ Aby uzyskać reprezentatywną listę rezultatów w procesie przeszukiwania bazy, sformułowano bardzo szeroką instrukcję wyszukiwawczą - „altmetrics OR «article level metrics» OR ALM". Proces wyszukiwania zainicjowano w polu topic, co pozwoliło na penetrację takich elementów rekordów bibliograficznych, jak słowa kluczowe nadane przez autora, słowa kluczowe, streszczenie i tytuł publikacji. Ponieważ założeniem była weryfikacja obecności zagadnień dotyczących wskaźników altmetrycznych na łamach publikacji należących do różnych dziedzin i dyscyplin nauki, poszukiwania przeprowadzono w obrębie wszystkich występujących na platformie indeksów cytowań (z zakresu nauk społecznych, ścisłych oraz nauk humanistycznych i sztuki).

${ }^{2}$ Proces wyszukiwania przeprowadzono za pomocą analogicznej instrukcji wyszukiwawczej „altmetrics OR «article level metrics» OR ALM", zasięg chronologiczny: 1967-2017, tj. od powstania bazy LISTA do dnia 15 marca $2017 \mathrm{r}$.

${ }^{3}$ Baza wyróżnia recenzowane czasopisma naukowe (ang. academic journals), periodyki branżowe (ang. trade publications) i wydawnictwa o charakterze popularnym - drukowane i elektroniczne gazety, newslettery, biuletyny, przeglądy itp. (ang. magazines).

${ }^{4} \mathrm{Z}$ dalszych analiz wykluczono: 1 . artykuły zawierające recenzje i przeglądy piśmiennictwa, 2. artykuły redakcyjne (ang. editorial), 3. relacje z konferencji i sympozjów, 4. rekomendacje wydawnicze, 5. wywiady (z bibliotekarzami, naukowcami i przedstawicielami firm oferujących aplikacje agregujące wskaźniki altmetryczne), 6. artykuły, które nie zostały wyposażone w anglojęzyczne
} 
tykuły. Wśród nich aż 120 (ze 146 ogółem) stanowiły publikacje ustalone $\mathrm{w}$ pierwszym etapie wyszukiwania, $\mathrm{tj}$. $\mathrm{w}$ bazie WoS CC. Z pozostałych 26 dokumentów pochodzących z WoS CC do zbioru badawczego włączono 22 pozycje (4 nie dotyczyły badanego zagadnienia). Ostatecznie zasób przewidziany do dalszej analizy formalnej i treściowej utworzyły 244 artykuły (rekordy bibliograficzne).

\section{ANALIZA FORMALNA}

Analiza dat wydania dokumentów dowiodła, że wzmożone zainteresowanie tematyką altmetrii $\mathrm{w}$ piśmiennictwie fachowym obserwuje się od 2013 r. O ile okres pomiędzy rokiem 2009 a 2012 cechował się jeszcze umiarkowanym przyrostem liczby artykułów, to na lata 2014-2016 przypadła największa koncentracja uwagi na tym zagadnieniu (por. Wykr. 2).

Ponieważ $\mathrm{w}$ analizach uwzględniono wyłącznie publikacje wydane do 15 marca 2017 r., na wykresie widoczny jest wyraźny spadek liczby

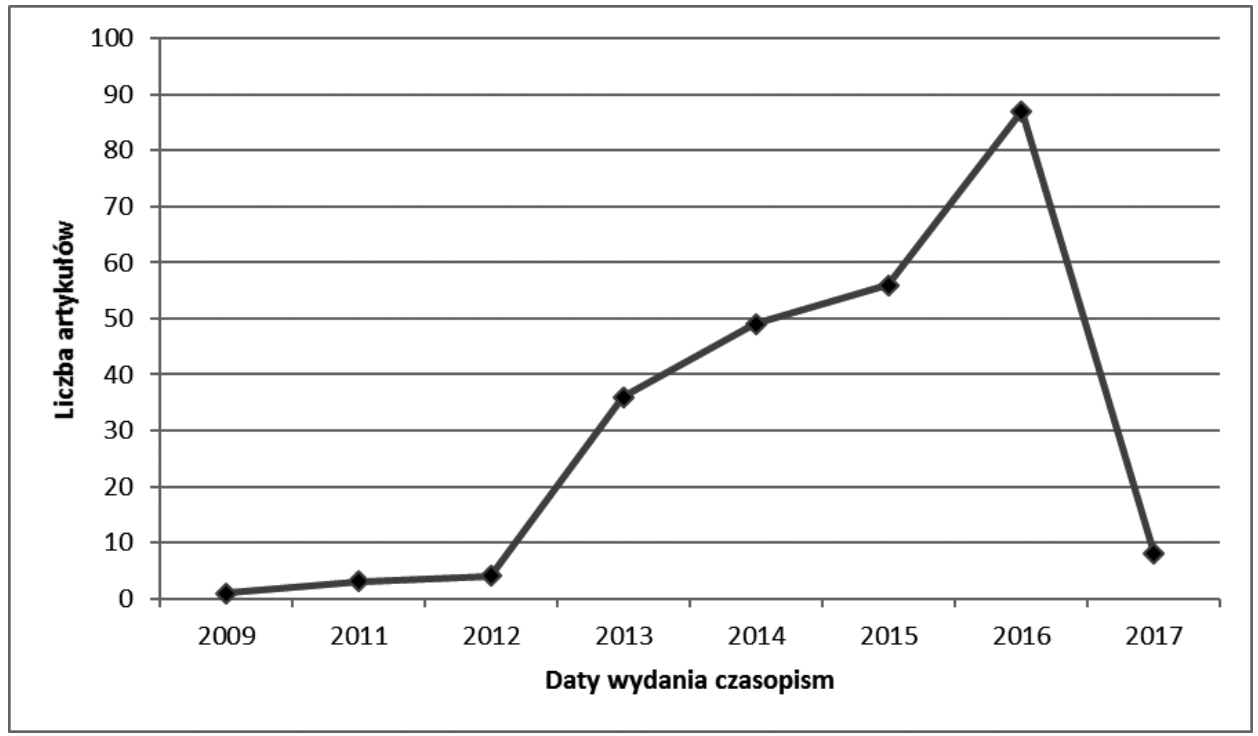

Wykres 1. Problematyka altmetrii na łamach czasopism z zakresu biblio- i informatologii w latach 2009-2017

Źródło: Oprac. własne.

streszczenia autorskie ( $w$ tej grupie wyjątek stanowiły dwa teksty opublikowane w języku polskim), 7. artykuły anonsujące rozpoczęcie prac zmierzających do opracowania standardów wskaźników altmetrycznych (m.in. pozyskanie grantów, powołanie grup roboczych, uruchomienie konsultacji społecznych itp.), 8. artykuły tematyczne niedotyczące zagadnienia altmetrii (np. posiadające w streszczeniu akronim ALM, odnoszący się do nazw firm i instytucji czy też innych terminów niż article-level metrics). 


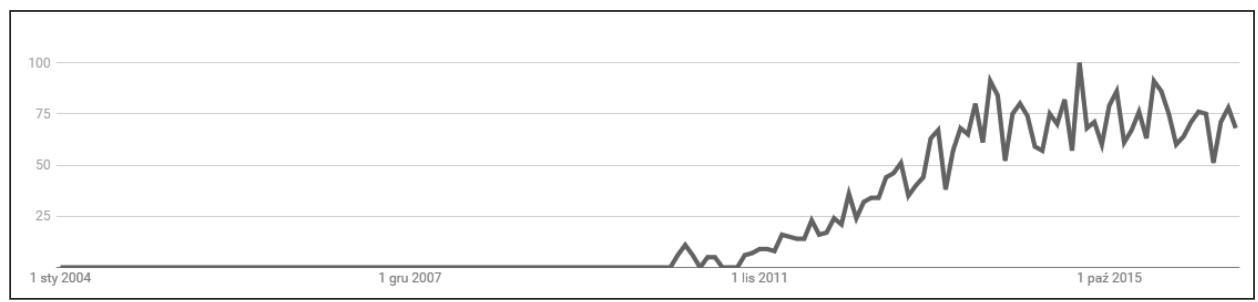

Wykres 2. Zainteresowanie problematyką metryk alternatywnych na świecie w latach 2004-2017

Źródło: „altmetrics” (2017). [online]. Google Trends [dostęp: 31.03.2017]. Dostępny w WWW: <https://trends.google.pl/trends/explore?date=all\&q=altmetrics $>$.

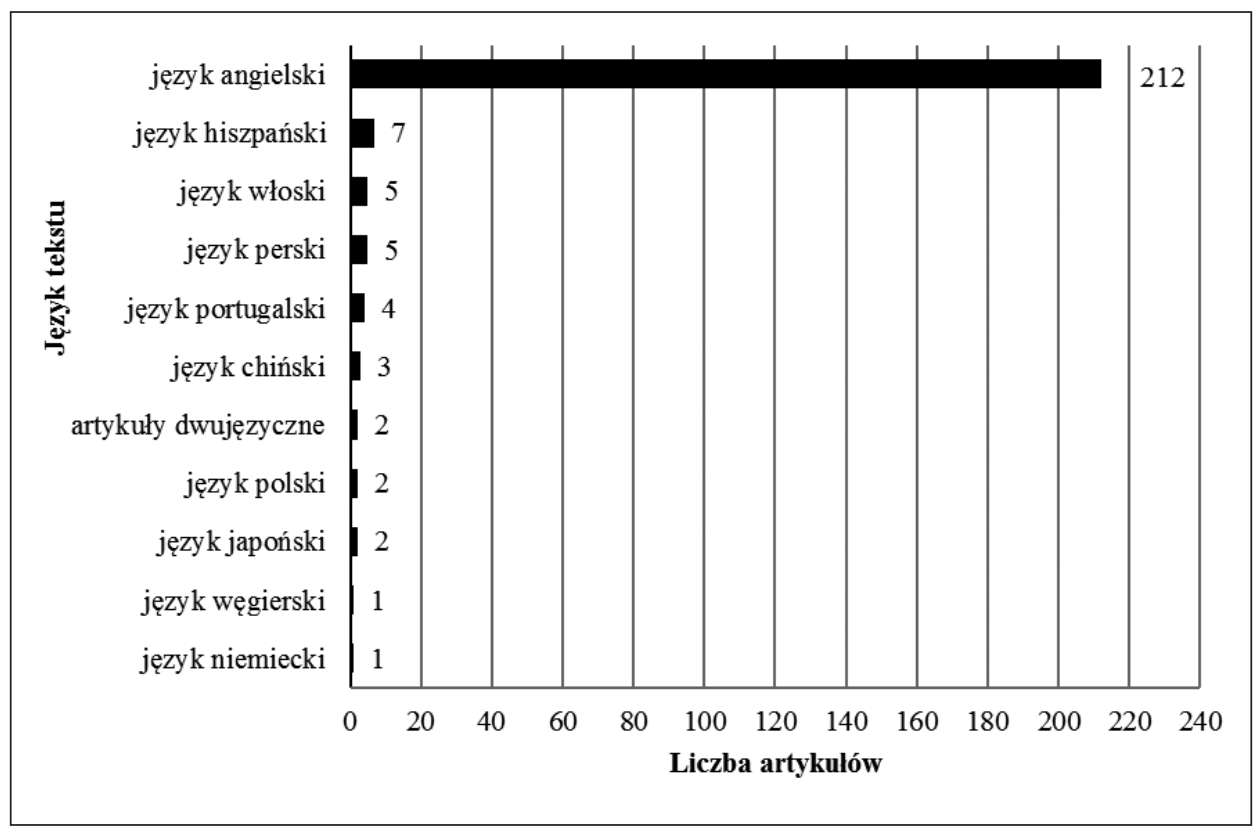

Wykres 3. Artykuły na temat altmetrii według kryterium językowego

Źródło: Oprac. własne.

publikacji po 2016 r. Jeśli jednak odnotować, że w roku 2015 i 2016 ukazało się najwięcej tekstów, można ostrożnie prognozować, że liczba artykułów będzie nadal wzrastać. Rosnące zainteresowanie problematyką altmetrii pokazuje także analiza zapytań z hasłem „altmetrics” kierowanych do wyszukiwarki Google.

Pod względem językowym w analizowanym materiale dominowały artykuły wydane w języku angielskim (212). Na kolejnych miejscach uplasowały się publikacje w języku hiszpańskim (7 dokumentów), perskim 
i włoskim - po 5 dokumentów, portugalskim - 4 i chińskim - 3 oraz japońskim i polskim - po 2. Odnotowano również po jedynym artykule w języku niemieckim i węgierskim. Dwa artykuły w zbiorze miały postać dwujęzyczna, tj. wyposażone zostały $\mathrm{w}$ równoległy tekst $\mathrm{w}$ języku hiszpańskim i angielskim. Taka struktura językowa zgromadzonego materiału nie dziwi, wynika bowiem $\mathrm{z}$ faktu, że analizie poddane zostały przede wszystkim czasopisma o zasięgu międzynarodowym, publikujące artykuły w języku angielskim.

Najczęstszym źródłem publikowanych artykułów było czasopismo "Scientometrics" (40 artykułów). Dość pokaźna, ale jednak znacznie mniejsza, liczba artykułów (od 10 do 20 pozycji) ukazała się na łamach takich periodyków, jak „Profesional de la Informacion”, ,Journal of the Association for Information Science and Technology" i "Journal of Informetrics". W przypadku pozostałych zidentyfikowanych w bazach czasopism liczba artykułów tematycznie dotyczących wskaźników altmetrycznych nie przekroczyła 10 (por. Tab. 1).

Dane z tabeli dowodza, że problematyka altmetrii podejmowana jest przede wszystkim na łamach periodyków sprofilowanych na badania wpływu dorobku naukowego z wykorzystaniem metod ilościowych, takich jak choćby "Scientometrics" czy "Journal of Informetrics”. Pokaźna liczba artykułów ukazuje się także w czasopismach poruszających kwestie gromadzenia, opracowywania i oceny zasobów informacji oraz dedykowanych technologiom informacyjnym, jak np. ,Journal of the Association for Information Science and Technology" i „El Profesional de la Informacion".

\section{ANALIZA TREŚCIOWA}

Analiza streszczeń odautorskich 244 artykułów wykazała, że zainteresowania autorów koncentrowały się na czterech różnych obszarach tematycznych związanych z altmetria, tj.:

- obszar 1: zagadnieniach ogólnych wprowadzających w problematykę nowego rodzaju metryk (62 artykuły),

- obszar 2: badaniach istnienia korelacji między altmetrykami a indykatorami tradycyjnymi (87 artykułów),

- obszar 3: kwestiach funkcjonalności i użyteczności aplikacji, serwisów, platform będących źródłem wskaźników oraz narzędzi je agregujących (82 artykuły),

- obszar 4: problemach normalizacji altmetryk (13 artykułów)

\footnotetext{
${ }^{5}$ Mimo tego, że w wielu artykułach podejmowano kilka różnych kwestii dotyczących altmetryk, autorka zdecydowała o jednokrotnym przydziale danego artykułu do jednego z czterech obszarów tematycznych. W ramach charakterystyki poszczególnych grup tematycznych przytoczono jedynie wybrane przykłady artykułów je reprezentujących.
} 
Tabela 1

Tytuły czasopism zidentyfikowane na podstawie rekordów bazy LISTA i WoS CC, w których w latach 2009-2017 opublikowano największą liczbę artykułów dedykowanych altmetrii (powyżej 1 artykułu)

\begin{tabular}{|c|c|}
\hline Tytuł czasopisma & $\begin{array}{c}\text { Liczba } \\
\text { artykułów }\end{array}$ \\
\hline Scientometrics & 40 \\
\hline Journal of the Association for Information Science and Technology & 14 \\
\hline El Profesional de la Informacion & 13 \\
\hline Journal of Informetrics & 13 \\
\hline Information Processing \& Management & 7 \\
\hline ASLIB Journal of Information Management & 7 \\
\hline Against the Grain & 7 \\
\hline Advanced Technology Libraries & 6 \\
\hline Bulletin of the Association for Information Science \& Technology & 6 \\
\hline Information Standards Quarterly & 6 \\
\hline Online Information Review & 6 \\
\hline Learned Publishing & 5 \\
\hline Charleston Advisor & 4 \\
\hline CILIP Update & 4 \\
\hline Evidence Based Library \& Information Practice & 4 \\
\hline Library Journal & 4 \\
\hline Insights: the UKSG Journal & 4 \\
\hline Research Information & 4 \\
\hline Biblioteche Oggi & 3 \\
\hline D-lib Magazine & 3 \\
\hline Information Services \& Use & 3 \\
\hline Information Today & 3 \\
\hline Library Technology Reports & 3 \\
\hline Multimedia Information \& Technology & 3 \\
\hline Bulletin of the American Society for Information Science \& Technology & 2 \\
\hline College \& Research Libraries & 2 \\
\hline Computers in Libraries & 2 \\
\hline EBIB - Electronic Bulletin for Librarians & 2 \\
\hline Information Research & 2 \\
\hline Journal of Library \& Information Studies & 2 \\
\hline Journal of Medical Internet Research & 2 \\
\hline Liber Quarterly: the Journal of European Research Libraries & 2 \\
\hline New Library World & 2 \\
\hline
\end{tabular}




\begin{tabular}{|l|c|}
\hline Online Searcher & 3 \\
\hline Perspectivas em Ciencia da Informacao & 2 \\
\hline Publishing Research Quarterly & 2 \\
\hline Science \& Technology Libraries & 2 \\
\hline Serials Librarian & 2 \\
\hline Serials Review & 2 \\
\hline
\end{tabular}

Źródło: Oprac. własne.

Najliczniej w badanym zbiorze reprezentowane były artykuły z obszaru drugiego. W większości z nich zestawiano liczbę cytowań poszczególnych publikacji z liczbą ich metryk alternatywnych. Od strony źródeł tradycyjnych wskaźników obiektem analiz były przede wszystkim cytowania pochodzące $z$ bazy danych Scopus (np. Maflahi, Thelwall, 2016) oraz indeksów umieszczonych na platformie Web of Science (np. Vélez-Cuartas, Lucio-Arias, Leydesdorff, 2016). Zdecydowanie rzadziej powoływano się na dane z repozytorium PubMed Central czy bazy danych ProQuest. Od strony źródeł metryk alternatywnych przedmiotem zainteresowania badaczy były głównie menedżer bibliografii Mendeley (np. Thelwall, Wilson, 2016), serwis Twitter (np. Haustein et al., 2014), platforma Public Library of Science (np. Linn, 2012) oraz umożliwiająca kolaboratywne rekomendowanie publikacji z nauk biologicznych i medycyny witryna „Faculty of 1000” (np. Ebrahimy, Setareh, 2016). Dużym zainteresowaniem cieszyły się również badania profili w serwisach społecznościowych dla naukowców, zwłaszcza ResearchGate, Academia.eu i Google Scholar (np. Hoffmann, Lutz, Meckel, 2016). Z mniejszą częstotliwością odwoływano się z kolei do metryk pochodzących z naukowych blogów czy serwisów, takich jak BibSonomy, Figshare, CiteULike, Goodreads, Facebook, Google+, LinkedIn i Slideshare. Najczęściej analizom porównawczym poddawane były artykuły z czasopism, rzadziej - całe wydawnictwa ciągłe (np. Onyancha, 2017) czy monografie (np. Snijder, 2016). Badaniami obejmowano artykuły bazujące na dorobku wielu dziedzin i dyscyplin naukowych (np. medycyna, astronomia, fizyka, chemia, inżynieria, biologia, rolnictwo, zarządzanie, socjologia, biblio- i informatologia, fizyka, chemia, inżynieria, zob. np. Sheppard, 2015) powstałe w różnych krajach świata (m.in. Stany Zjednoczone, Hiszpania, Szwecja, Indie, Malezja, Tajwan - zob. np. Chen et al. 2015). Głównymi celami przeprowadzanych analiz były próby określania poziomu obecności badaczy krajowych w międzynarodowych bazach danych, indeksach cytowań bibliograficznych oraz mediach społecznościowych (np. Ortega, 2016), zbadania korelacji występujących pomiędzy liczbą cytowań a liczbą metryk alternatywnych (np. Akbulut, 2015; Shrivasta, Shrivastva, Mahajan, 2016), dyskredytacji cytowań jako skutecznego indykatora oceny 
dorobku z jednej strony i eksponowania korzyści płynących z wykorzystywania metryk alternatywnych - z drugiej (Eysenbach, 2011). Podejmowano również starania zmierzające do wytypowania najbardziej efektywnego źródła nowego rodzaju metryk (np. De Winter, 2015). O ile na poziomie pojedynczego artykułu najczęściej krytykowanym czy budzącym liczne kontrowersje wskaźnikiem oceny była liczba cytowań, to na poziomie czasopisma wskaźnikiem takim był impact factor (np. Thelwall, Fairclough, 2015). W kilku artykułach krytyce poddano również inne mierniki, w tym indeks SCImago Journal Rank i Source-Normalized Impact per Paper(np. Roemer, Borchadt, 2012) oraz indeks Hirscha (np. Dhiman, 2015).

Na drugim miejscu pod względem liczebnym uplasowały się artykuły z pierwszego obszaru tematycznego. W grupie tej znalazły się prace wyjaśniające istotę alternatywnych wskaźników (w kontekście dotychczasowych mierników oceny, np. Barros, 2015); dokonujące przeglądu literatury fachowej na ten temat (np. González-Valiente et al., 2016) prezentujące poziom świadomości różnych grup użytkowników w tym obszarze (np. Malone, Burke, 2016); eksponujące rolę, potencjał (także w kontekście dotychczasowych agregatorów danych, np. Konkiel, Scherer, 2013) i ograniczenia nowego rodzaju metryk (np. Galligan, 2013); charakteryzujące ich rodzaje (np. Ming-Yueh, Ling-Li, 2014); a wreszcie - dowodzące ich przydatności dla różnych grup interesariuszy, w tym badaczy, wydawców, decydentów i bibliotekarzy (np. Mehraban, Mansourian, 2014).

Kolejną pozycję w rankingu zajęły artykuły z obszaru trzeciego. W ich zbiorze najliczniej reprezentowane były teksty opisujące poszczególne źródła metryk alternatywnych (m.in. ich genezę, dostępne dla użytkownika funkcje, rodzaje mierników umożliwiających ocenę dorobku, liczbę założonych profili lub aktywnych użytkowników itp., np. Megwalu, 2015). W odróżnieniu od artykułów z obszaru drugiego, w tekstach przypisanych do obszaru trzeciego aktywności badaczy w mediach społecznościowych nie zestawiano z tradycyjnie rozumianymi cytowaniami. Dany serwis/witrynę/aplikację omawiano tu przede wszystkim z punktu widzenia dwóch perspektyw: po pierwsze, w kontekście możliwości pełnienia roli potencjalnego źródła alternatywnych metryk (np. Orduña-Malea, Martin-Martin, 2015), po drugie, pod kątem obecności w nim przedstawicieli danej dziedziny, identyfikacji realizowanych form aktywności czy oceny zasięgu tworzonej sieci kontaktów (np. Álvarez-Bornstein, Montesi, 2016). Podejmowano także nieliczne próby kategoryzacji użytkowników poszczególnych serwisów (np. Mohammadi et al., 2015). Wśród artykułów zakwalifikowanych do obszaru trzeciego znalazły się jeszcze teksty przybliżające funkcjonalności narzędzi agregujących metryki alternatywne (najczęściej opisywane były Altmetric Explorer, Impactstory, 


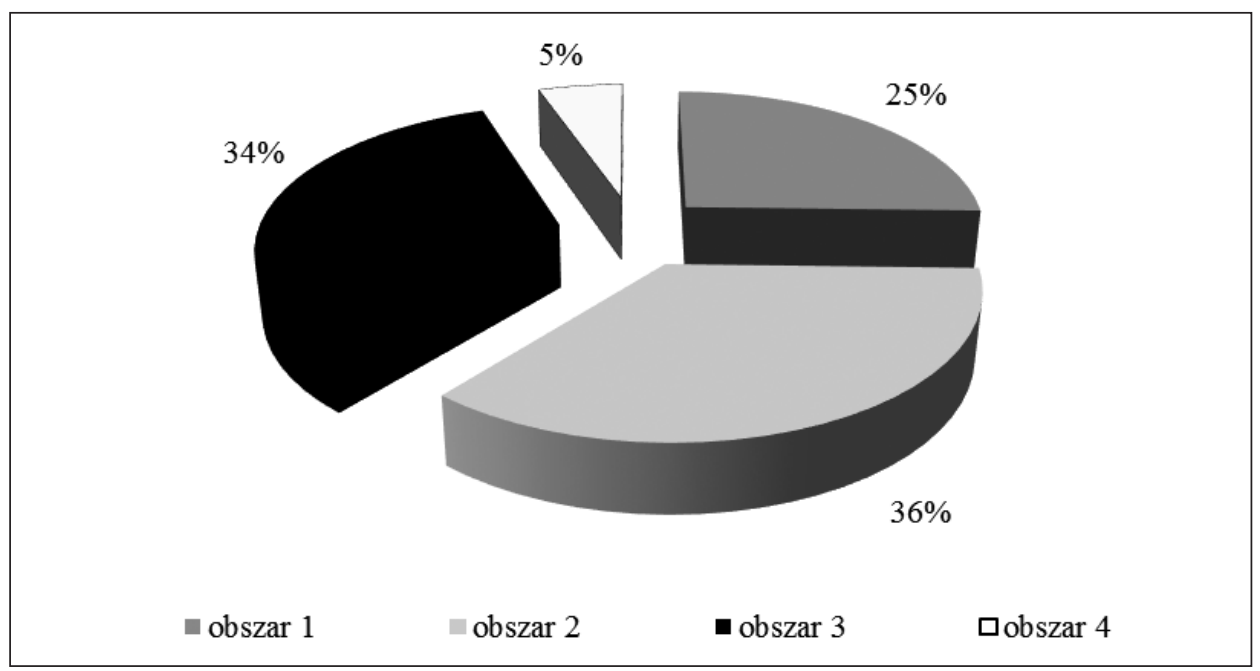

Wykres 4. Procentowy rozkład zagadnień dotyczących altmetrii poruszanych na łamach artykułów z czasopism z zakresu biblio- i informatologii w latach 2009-2017

Źródło: Oprac. własne.

PlumX, PLoS Article-Level Metrics/Lagotto, zob. np. Adam, 2014) oraz artykuły informujące o rozpoczęciu procesu integracji konkretnych baz danych (np. Real-time citation..., 2016), repozytoriów (np. Figshare to display ..., 2016), wyszukiwarek (np. Free, 2016), portali (np. Dos Santos Ribeiro, Camargo, 2016) i platform czasopism (np. Wiley adds altmetric..., 2014) z tymi narzędziami.

Najskromniejszy pod względem liczebnym okazał się obszar czwarty. Artykuły zgromadzone w tej grupie tematycznej oscylowały wokół zagadnień normalizacji i standaryzacji wskaźników altmetrycznych. Część autorów wypowiadała się bardzo ogólnie o konieczności integracji nowego rodzaju metryk z tradycyjnymi indykatorami (np. Moed, Halevi, 2015), inni ograniczali się do komentowania propozycji National Information Standards Organization (dalej: NISO) w tym zakresie (O'Neill, 2016), jeszcze inni z kolei postulowali potrzebę wprowadzenia specjalnych wskaźników wpływu dla konkretnych źródeł metryk - najczęściej Twittera i Mendeleya (np. Bornmann, Hauschild, 2016a, 2016b, 2016c).

\section{PODSUMOWANIE}

Analiza zebranego materiału wyraźnie wykazała, że problematyka wskaźników alternatywnych jest zagadnieniem chętnie podejmowanym przez badaczy na świecie. Zagadnienie to bywa rozpatrywane przede wszystkim z punktu widzenia potencjalnej przewagi nowego rodzaju 
metryk nad tradycyjnymi miernikami oceny dorobku naukowego oraz w kontekście badania efektywności elektronicznych źródeł i narzędzi pomiaru społecznego wpływu nauki. Jak wynika z przeprowadzonych badań, większość badaczy reprezentuje pogląd o dużej użyteczności alternatywnych wskaźników zwłaszcza dla takich dziedzin, które choćby ze względu na lokalny zakres badań - są marginalnie reprezentowane w zasobach światowych baz danych (np. nauki humanistyczne). Jak dowodzą autorzy, mierniki te pozwalają w znacznie szybszym tempie niż wskaźniki tradycyjne zwiększać widoczność, a przez to popularyzować własny dorobek publikacyjny (por. Cassella, 2015; Maflahi, Thelwall, 2016).

Mimo że w wielu analizowanych publikacjach dowodzi się istnienia dodatnich korelacji pomiędzy liczbą cy towań a liczbą alternatywnych metryk (w większości przypadków wraz ze wzrostem cytowań rośnie liczba altmetryk lub to mierniki alternatywne determinują częstsze cytowania), żaden z badaczy nie wysuwa propozycji zastąpienia tradycyjnych cytowań metrykami społecznościowymi. Wręcz przeciwnie - większość badaczy reprezentuje sceptyczny pogląd i uważa, że mogą one stać się co najwyżej uzupełniającym elementem oceny danego badacza (np. Adie, 2014; Moed, Halevi, 2015). Stanowisko takie wypływa przede wszystkim z - omówionych już w niniejszym artykule - zastrzeżeń formułowanych wobec alternatywnych wskaźników, tj. tymczasowości oceny, podatności na manipulację, nieuwzględniania dorobku badaczy starszego pokolenia i braku standaryzacji.

Ponieważ wskaźniki alternatywne mają szansę w przyszłości stać się komponentem swoistej metaanalizy dorobku naukowego, szczególnie istotna wydaje się kwestia ich standaryzacji i normalizacji. Na pewne rozwiązania w tym zakresie wskazują zarówno sami badacze, sugerując m.in. konieczność wprowadzenia współczynników wpływu, czy też indeksów dla konkretnych źródeł metryk i narzędzi je agregujących (por. Bornmann, Haunschid, 2016a, 2016b, 2016c), jak i organizacje standaryzacyjne, takie jak NISO. Ta ostatnia jesienią 2016 r. w dokumencie Outputs of the NISO Alternative Assessment Metrics Project.A Recommended Practice of the National Information Standards Organization stworzyła swoiste wytyczne dla dostawców danych altmetrycznych (Altmetrics Data Quality Code of Conduct). Ich celem jest poprawa jakości danych altmetrycznych, a więc zwiększenie przejrzystości metod ich dostarczania i agregowania oraz zapewnienie replikowania i precyzji w zakresie oceniania zdarzeń online wykorzystywanych do ich generowania. W opracowanych zaleceniach dostawców danych i właścicieli narzędzi agregujących zachęca się do przygotowywania raportów informujących o rodzajach agregowanych danych, metodach ich dostarczania i aktualizacji, sposobach monitorowania ich jakości, a wreszcie formach udostępniania 
użytkownikom i wszystkich ograniczeń z tego wynikających ${ }^{6}$. Wydaje się, że przestrzeganie tych zaleceń mogłoby stanowić pierwszy poważny krok w kierunku normalizacji altmetryk, a w przyszłości przełożyć się na wypracowanie dobrych praktyk w tym zakresie.

\section{BIBLIOGRAFIA}

„altmetrics" (2017). [online]. Google Trends [dostęp: 31.03.2017]. Dostępny w WWW: <https://trends.google.pl/trends/explore?date=all\&q=altmetrics .

Adam, Michaele (2014). Bibliometrics 2.0 - Altmetrics in medicine. GMS Medizin - Bibliothek - Information, vol. 14, iss. 3, pp. 1-8.

Adie, Euan (2014). Taking the alternative mainstream. El Profesional de la Informacion, vol. 23, iss. 4, pp. 349-351.

Akbulut, Müge (2015). Relationship between traditional metrics and altmetrics: a case analysis of PLoS, Information World, vol. 16, iss. 2, pp. 275-285.

Altmetrics for Researchers (2015), [online]. Duke University. Medical Center Library \& Archives [dostęp: 31.03.2017]. Dostępny w WWW: <http://guides.mclibrary.duke.edu/ altmetrics/home>.

Álvarez-Bornstein, Belén; Montesi, Michaela (2016). Researchers' communication on Twitter. A virtual ethnography in the area of information science. Revista Espanola de Documentacion Cientifica, vol. 39, iss. 4, pp. 1-15.

Barnes, Cameron (2015). The use of altmetrics as a tool for measuring research impact. Australian Academic \& Research Libraries, vol. 46, iss. 2, pp. 121-134.

Barros, Moreno (2015). Altmetrics: Alternative metrics of scientific impact based on social media. Perspectivas em Ciencia da Informacao, vol. 20. iss. 2, pp. 19-37.

Bornmann, Lutz (2014). Do altmetrics point to the broader impact of research? An overview of benefits and disadvantages of altmetrics. Journal of Informetrics, vol. 8, iss. 4, pp. 895-903.

Bornmann, Lutz; Haunschild, Robin (2016a). How to normalize Twitter counts? A first attempt based on journals in the Twitter Index, Scientometrics, vol. 107, iss. 3, pp. 14051422.

Bornmann, Lutz; Haunschild, Robin (2016a). Normalization of Mendeley reader impact on the reader- and paper-side: A comparison of the mean discipline normalized reader score (MDNRS) with the mean normalized reader score (MNRS) and bare reader counts. Journal of Informetrics, vol. 10, iss. 3, pp. 776-788.

Bornmann, Lutz; Haunschild, Robin (2016c). t factor: A metric for measuring impact on Twitter. Malaysian Journal of Library \& Information Science, vol. 21, iss. 2, pp. 13-20.

Cassella, Maria (2015). La valutazione della monografia accademica di ricerca. Biblioteche Oggi, vol. 33, pp. 12-21.

\footnotetext{
${ }^{6}$ W wytycznych NISO zaproponowano trzy kryteria opisu altmetryk: transparentność (transparency), replikacja (replicability) i precyzja/dokładność (accuracy). Każde z kryteriów oznaczono odpowiednim symbolem, który zalecono umieszczać przy jego opisie. W załączniku B do wytycznych zamieszczono klika przykładowych raportów wybranych dostawców i agregatorów danych altmetrycznych (Crossref, Facebook, Twitter, Wikipedia, PLoS, Plum Analytics, Mendeley) przygotowanych zgodnie z tymi wytycznymi (NISO, pp. 33-69).
} 
Chen, Kuang-hua et al. (2015). Exploring alternative metrics of scholarly performance in the social sciences and humanities in Taiwan. Scientometrics, vol. 102, iss. 1, pp. 97-112.

De Winter, Joost (2015). The relationship between tweets, citations, and article views for PLOS ONE articles. Scientometrics, vol. 102, iss. 2, pp. 1773-1779.

Dhiman, Anil Kumar (2015). Bibliometrics to Altmetrics: Changing trends in assessing research impact. DESIDOC Journal of Library \& Information Technology, vol. 35, iss. 4, pp. 310-315.

Dos Santos Ribeiro, Danielly; Camargo, Luiza Moreira (2016). Implementation of alternative metrics in Portal oasisbr. Cadernos de Biblioteconomia, Arquivistica e Documentacao, iss. 2, pp. 168-178.

Ebrahimy, Saeideh; Setareh, Fatemeh (2016). Research on alternative measures in the F1000 system with Google Scholar citation index. Journal of Information Processing \& Management, vol. 31, iss. 4, pp. 891-909.

Eysenbach, Gunther (2011). Can tweets predict citations? Metrics of social impact based on twitter and correlation with traditional metrics of scientific impact. Journal of Medical Internet Research [online], vol. 13, iss. 4 [dostęp: 31.02.2017]. Dostępny w WWW: <https://www.ncbi.nlm.nih.gov/pmc/articles/PMC3278109/>.

Fenner, Martin; Linn, Jeniffer (2015). ALM - nowatorskie metryki wskaźników wpływu w publikacjach naukowych. Biblioteka, nr 19, s. 235-246.

Figshare to display Altmetric badges (2016). Research Information, iss. 84, p. 34.

Free, David (2016). Altmetric data now available in Summon. College \& Research Libraries News, vol. 77, iss. 4, p. 173.

Galligan, Finbar; Dyas-Correia, Sharon (2013). Altmetrics: rethinking the way we measure. Serials Review, Vol, 39, iss. 1, pp. 56-61.

González-Valiente, Carlo Luis; Pacheco-Mendoza, Josmel; Arencibia-Jorge, Ricardo (2016). A review of altmetrics as an emerging discipline for research evaluation. Learned Publishing, vol. 29, iss. 4, pp. 229-238.

Gumpenberger, Christian; Glänzel, Wolfgang; Gorraiz, Juan (2016). The ecstasy and the agony of the altmetric score. Scientometrics, vol. 108, iss. 2, pp. 977-982.

Haustein, Stefanie et al. (2014). Astrophysicists on Twitter. An in-depth analysis of tweeting and scientific publication behavior. ASLIB Journal of Information Management, vol. 66, iss. 3, pp. 279-296.

Hoffmann, Christian Pieter; Lutz, Christoph; Meckel, Miriam (2016). A relational altmetric? Network centrality on ResearchGate as an indicator of scientific impact. Journal of Association for Information Science \& Technology, vol. 67, iss. 4, pp. 765-775.

Jaskowska, Małgorzata (2016).Wpływ wskaźników altmetrycznych na doskonalenie systemu oceny wartości prac naukowych w humanistyce. W: Sosińska-Kalata, Barbara; Przastek-Samokowa, Maria; Wiorogórska, Zuza red. Nauka o informacji w okresie zmian: informatologia i humanistyka cyfrowa. Warszawa: Wydaw. SBP, s. 179-193.

Konkiel, Stacy (2013). Altmetrics: A 21st-century solution to determining research quality. Information Today, [online], vol. 37, iss. 4 [dostęp: 31.03.207]. Dostępny w WWW: $<$ http://www.infotoday.com/OnlineSearcher/Articles/Features/Altmetrics-A-stCentury-Solution-to-Determining-Research-Quality-90551.shtml>.

Konkiel, Stacy; Scherer, Dave (2013). New opportunities for repositories in the age of altmetrics. Bulletin of the Association for Information Science \& Technology, vol. 39, iss. 4, pp. 22-26. 
Kwiek, Marek (2015). Uniwersytet $w$ dobie przemian. Instytucje i kadra akademicka w warunkach rosnacej konkurencji. Warszawa: PWN.

Linn, Jeniffer (2012). The measure of usage, the usage of measures: article level metrics at PLoS. Against the Grain, vol. 24, iss. 4, pp. 42-46.

Maflahi, Nabeil; Thelwall, Mike (2016). When are readership counts as useful as citation counts? Scopus versus Mendeley for LIS Journals. Journal of the Association for Information Science \& Technology, vol. 67, iss. 1, pp. 191-1999.

Malone, Tara; Burke, Susan (2016). Academic librarians' knowledge of bibliometrics and altmetrics. Evidence Based Library \& Information Practice, vol. 11, iss. 3, pp. 34-49.

Megwalu, Anamika (2015). ResearchGate: an academic social networking site. Charleston Advisor, vol. 17, iss. 1, pp. 47-51.

Mehraban, Sarah; Mansourian, Yazdan (2014). Tracking scientific trends: scientometrics methods and metrics, and the change in librarians' roles. Journal of Information Processing and Management, vol. 29, iss. 3, pp. 1-20.

Melero, Remedios (2015). Altmetrics - a complement to conventional metrics. Biochemia Medica (Zagreb) [online], vol. 25, iss. 2 [dostęp: 31.03.2017]. Dostępny w WWW: <https://www.ncbi.nlm.nih.gov/pmc/articles/PMC4470104/>.

Ming-Yueh, Tsay; Ling-Li, Tseng (2014). An introductory review of altmetrics. Journal of Educational Media \& Library Sciences, vol. 51, Special Iss, pp. 91-120.

Moed, Henk F.; Halevi, Gali (2015). Multidimensional assessment of scholarly research impact. Journal of the Association for Information Science \& Technology, vol. 66, iss. 10, pp. 1988-2002.

Mohammadi, Ehsan et al. (2015). Who reads research articles? An altmetrics analysis of Mendeley user categories. Journal of the Association for Information Science \& Technology, vol. 66, iss. 9, pp. 1832-1846.

NISO (2016). Outputs of the NISO Alternative Assessment Metrics Project.A Recommended Practice of the National Information Standards Organization, [online]. National Information Standards Organization [dostęp: 31.03.2017]. Dostępny w WWW: <http://www.niso. org/apps/group_public/download.php/17091/NISO RP-25-2016 Outputs of the NISO Alternative Assessment Project.pdf $>$.

O'Neill, Jill (2016). NISO recommended practice: Outputs of the Alternative Assessment Metrics Project. Collaborative Librarianship, vol. 8, iss. 3, pp. 118-123.

Onyancha, Omwoyo (2017). Altmetrics of South African journals: implications for scholarly impact of South African research. Publishing Research Quarterly, vol. 33, iss. 1, pp. 71-91.

Orduña-Malea, Enrique; Martin-Martin, Alberto; Lopez-Cozar, Emilio Delgado (2015). ResearchGate as a source for scientific evaluation: revealing its bibliometric application. El Profesional de la Informacion, vol. 25, iss. 2, pp. 303-310.

Ortega, José Luis (2015). Disciplinary differences in the use of academic social networking sites. Online Information Review, vol. 39, iss. 4, pp. 520-536.

Ortega, José Luis (2016). To be or not to be on Twitter, and its relationship with the tweeting and citation of research papers. Scientometrics, vol. 109, iss. 2, pp. 1353-1364.

Osiński, Zbigniew (2012). Bibliometria metodą analizy i oceny dorobku naukowego historyków najnowszych dziejów Polski. W: Dymmel, Anna; Rejakowa, Bożena red. Kultura, historia, ksiażka: zbiór studiów. Lublin: UMCS, s. 605-616.

Priem, Jason et al. (2010). Altmetrics: A manifesto, [online]. Altmetrics.org [dostęp: 31.03.2017]. Dostępny w WWW: <http://altmetrics.org/manifesto/>.

Real-time citation tool (2016). CILIP Update, iss. 6, p. 18. 
Robinson-Garcia, Nicolás et al. (2014) New data, new possibilities: exploring the insides of Altmetric.com. El Profesional de la Informacion, vol. 23, iss. 4, pp. 359-366.

Roemer, Robin Chin; Borchadt, Rachel (2012). From bibliometrics to altmetrics. College \& Research Libraries News, vol. 73, iss. 10, pp. 596-600.

Roemer, Robin Chin; Borchadt, Rachel (2015). issues, controversies, and opportunities of altmetrics. Library Technology Reports, vol. 51, iss. 5, pp. 20-30.

Ross, Mounce (2013). Open Access and Altmetrics: Distinct but Complementary. Bulletin of Association for Information Science \& Technology, Vo. 39, iss. 4, pp. 14-17.

Rothe, Robin; Schmitz Jasmin (2016). Die mögliche Vielfalt der Impact-Messung: Anbietervergleich von Aggregatoren von Altmetriken [online]. ZB MED-Blog [dostęp: 31.03.2017]. Dostępny w WWW: <http://zbmedblog.de/?p=383>.

Rychlik, Małgorzata(2013). Epoka cyfrowa i jej nowe wskaźniki altmetryczne. Biuletyn EBIB [online], nr 144 [dostęp: 31.03.2017]. Dostępny w WWW: <http://open.ebib.pl/ ojs/index.php/ebib/article/view/121/271>.

Sheppard, Beth (2015). By the numbers: bibliometrics and altmetrics as measures of faculty impact in the field of religion. Theological Librarianship, vol. 8, iss. 2, pp. 28-36.

Shrivastva, Rishabh; Mahajan, Preeti (2016). Relationship between citation counts and Mendeley readerships metrics. New Library World, vol. 117, iss. 3/4, pp. 229-238.

Snijder, Ronald (2016). Revisiting an open access monograph experiment: measuring citations and tweets 5 years later. Scientometrics, vol. 109, iss. 3, pp. 1855-1875.

Thelwall, Mike; Fairclough Ruth (2015). Geometric journal impact factors correcting for individual highly cite articles. Journal of Informetrics, vol. 9, iss. 2, pp. 263-272.

Thelwall, Mike; Wilson, Paul (2016). Mendeley readership altmetrics for medical articles: an analysis of 45 fields. Journal of Association for Information Science \& Technology, vol. 67, iss. 8, pp. 1962-1972.

Vélez-Cuartas, Gabriel; Lucio-Arias, Diana; Leydesdorff Loet (2016). Regional and global science: publications from Latin America and the Caribbean in the SCIelo Citation Index and the Web of Science. El Profesional de la Informacion, vol. 25, iss. 1, pp. 35-46.

Wiley adds altmetric data to journal program (2014). Advanced Technology Libraries, vol. 43, iss. 8 , pp. $4-5$.

Artykuł w wersji poprawionej wptyną do Redakcji 4 lipca 2017 r. 
MAŁGORZATA KOWALSKA

Institute of Information and Book Studies

Nicolaus Copernicus University in Torun

e-mail: koma@umk.pl

\section{ALTMETRICS AS AN AREA OF INTEREST IN THE FIELD OF LIBRARY AND INFORMATION SCIENCE}

KEYWORDS: Altmetrics. Library and information science. Alternative metrics. Assessment of research input.

ABSTRACT: Thesis/Objective - The author discusses the significance of alternative metrics in the assessment of research input and attempts to show if this issue is of any interest to to the researchers in the library and information science. Research methods - Using the analysis of the content of the library and information science journals, the author identifies the most popular topics related to altmetrics. Conclusions - The research done by the author proves altmetrics to be very popular issue discussed in the library and information science literature, in particular for the last three years. In the author's opinion the interest in altmetrics will survive and continue to grow and alternative metrics will play an important role in the assessment of the research input. 